NBER WORKING PAPER SERIES

CRIME, URBAN FLIGHT, AND THE

CONSEQUENCES FOR CITIES

Julie Berry Cullen

Steven D. Levitt

Working Paper 5737

\author{
NATIONAL BUREAU OF ECONOMIC RESEARCH \\ 1050 Massachusetts Avenue \\ Cambridge, MA 02138 \\ September 1996
}

We would like to thank Daron Acemoglu, Philip Cook, David Cutler, Jonathan Gruber, Jerry Hausman, Lawrence Katz, John Lott, David Mustard, James Poterba, William Wheaton, and seminar participants at Harvard, MIT, and the University of Pennsylvania for helpful comments. We are grateful to Rich Robinson of CIESIN for providing the Census data extracts. Comments can be addressed either to Julie Berry Cullen, Building E-52, Department of Economics, Massachusetts Institute of Technology, Cambridge, MA 02142, or to Steven Levitt, Harvard Society of Fellows, 78 Mount Auburn Street, Cambridge, MA 02138. e-mail addresses: jberry@mit.edu; slevitt@fas.harvard.edu. The financial support of the National Science Foundation and the National Institute on Aging is gratefully acknowledged. All remaining errors are the sole responsibility of the authors. This paper is part of NBER's research program in Public Economics. Any opinions expressed are those of the authors and not those of the National Bureau of Economic Research.

(C) 1996 by Julie Berry Cullen and Steven D. Levitt. All rights reserved. Short sections of text, not to exceed two paragraphs, may be quoted without explicit permission provided that full credit, including (C) notice, is given to the source. 


\title{
CRIME, URBAN FLIGHT, AND THE \\ CONSEQUENCES FOR CITIES
}

\begin{abstract}
This paper demonstrates that rising crime rates in cities are correlated with city depopulation. Instrumental variables estimates, using measures of the certainty and severity of a state's criminal justice system as instruments for city crime rates, imply that the direction of causality runs from crime to urban flight. Using annual city-level panel data, our estimates suggest that each additional reported crime is associated with a one person decline in city residents. There is some evidence that increases in suburban crime tend to keep people in cities, although the magnitude of this effect is small. Analysis of individual-level data from the 1980 census confirms the city-level results and demonstrates that almost all of the crime-related population decline is attributable to increased outmigration rather than a decrease in new arrivals to a city. Those households that leave the city because of crime are much more likely to remain within the SMSA than those leaving the city for other reasons. The migration decisions of high-income households and those with children are much more responsive to changes in crime than other households. Crime-related mobility imposes costs on those who choose to remain in the city through declining property values and a shrinking tax base.
\end{abstract}

Julie Berry Cullen

Department of Economics, E52

Massachusetts Institute of Technology

Cambridge, MA 02142

jberry@mit.edu
Steven D. Levitt Harvard Society of Fellows 78 Mount Auburn Street Cambridge, MA 02138 and NBER slevitt@fas.harvard.edu 
The difficulties confronting large American cities in recent decades are well documented. ${ }^{1}$ The urban riots of the late 1960 s turned the post-war suburbanization trend into large-scale urban flight. A declining tax base, shrinking federal subsidies, tax limitations, and city residents in need of greater public services has pushed many cities to the brink of fiscal crisis. Among the greatest difficulties faced by large American cities is crime. Violent crime rates in U.S. cities with populations over 500,000 in 1993 were four times higher than in cities with populations below 50,000, and seven times greater than in rural areas. ${ }^{2}$ Higher crime rates in large cities are even more remarkable when one considers that both per capita expenditures on police and the level of victim precaution (e.g. locking doors, private security guards, alarm systems) are much greater in large cities. ${ }^{3}$

This paper examines the link between crime and urban flight. ${ }^{4}$ Although there is an extensive literature analyzing this subject le.g. Taeuber and Taeuber 1965, Bradford and Kelejian 1973, Frey 1979, Marshall 1979, Marshall and O'Flaherty 1987), there has been relatively little focus on the role of crime in explaining the phenomenon. A handful of studies have included the level of crime as a right-hand side variable in cross-city OLS

1 See, for instance, Bradbury, Downs, and Small (1982), Gottdeiner (1986), Wilson (1987), and Inman, Craig, and Luce (1994).

2 The Uniform Crime Reports, which reflect only those crimes reported to the police, are likely to understate the actual difference in crime rates across city types because of the greater likelihood a crime will be reported to the police in smaller cities (Levitt 1995).

3 In 1990-1991, cities with population over one million spent an average of $\$ 210$ per capita on police protection, whereas cities with populations below 75,000 residents expended an average of $\$ 97$ per capita (U.S. Department of Commerce 1993).

4 While urban flight is interesting in its own right, declines in city population are also correlated with increases in the percent of families below the poverty line in the city, the fraction of city residents failing to complete high school, and declines in median housing values. Thus, urban flight proxies for city decline more generally. 
estimates of urban flight. These studies typically obtain a positive relationship between crime rates and urban flight (e.g. Frey 1979, Grubb 1982, Katzman 1980, Sampson and Wooldredge 1986). ${ }^{5}$

In contrast to previous research on the topic, our analysis focuses primarily on the impact of changes in crime rates rather than levels. There are both theoretical and methodological justifications for examining changes in crime rates. From a theoretical perspective, the simplest residential choice model predicts that changes in crime rates, not levels, will influence changes in city population. ${ }^{6}$ On a practical level, focusing on changes mitigates problems associated with non-comparabilities in crime reporting rates, crime definitions, and police department practices across cities (O'Brien 1985).

Section I documents the strong empirical correlation between rising crime rates and central city population declines using a panel of 137 cities over the period 1976-1993. After controlling for other factors, each additional reported crime in a central city is associated with a net decline of about one resident. Higher suburban crime rates tend to keep people in central cities, although the magnitude of this effect is much smaller than for crimes within cities.

Of course, one cannot necessarily draw any causal conclusions from these

5 Previous research has also documented a positive relationship between population turnover and crime rates at the neighborhood level, especially in poor neighborhoods (Smith and Jarjoura 1988, Taylor and Covington 1988). In contrast to that literature, which focuses on gross flows of residents, our analysis is concerned with net population changes.

6 In a simple model where property values fully capitalize the costs and benefits of a location, then changes in amenities can be captured by changes in housing values without any net population change. Relocation costs and heterogeneous tastes affect the composition of the residents, but do not necessarily imply any change in the total number of city residents. In this paper, we take the empirical regularity of fluctuating city populations as a starting point, leaving the theoretical puzzle of why property values do not fully adjust for future work. 
estimates. While the most obvious causal link runs from rising crime rates to urban flight, it is also possible that an omitted third factor may be responsible for both rising crime and urban flight. For instance, if population loss in shrinking cities is disproportionately comprised of high income individuals (who tend to have lower rates of crime victimization), then the average crime rate among remaining city residents will rise, even if each resident's risk of victimization is unchanged. On the other hand, since crime rates are strongly positively correlated with city size, city growth is likely to be correlated with rising crime rates. If that is the case, OLS may understate the causal impact of crime on city population.

We attempt to establish a causal link between crime and urban flight through the use of instrumental variables in Section II. A valid instrument must affect the crime rate but not otherwise belong in the equation explaining city population changes. The logical source of such instruments is changes in the punitiveness of the criminal justice system. In particular, we use lagged changes in state prison commitments and state prison releases per crime. These variables are demonstrated to affect crime in the predicted manner, yet are plausibly excluded from the city population equation. The estimated impact of crime on city population using 2 SLS are slightly larger than the OLS estimates, suggesting that any bias in the OLS estimates resulting from omitted variables or compositional changes in city population is overwhelmed by the tendency for large cities to have higher crime rates.

A major limitation of the above panel-data analysis is that it addresses only aggregate population changes. Using PUMS data from the 5 percent sample of the 1980 census yields a number of additional insights in Section III. We are able to obtain estimated migration in and out of 81 U.S. cities by income category, race, and family status. Using census data, it is also possible to distinguish between increasing out-migration and 
declining in-migration and to identify the destinations of those who leave cities. Our results suggest that almost all of the impact of crime on city population results from increased outmigration; the link between changes in crime and in-migration appears weak. Seventy percent of those people leaving central cities due to crime remain within the SMSA, compared to forty percent of all central city out-migrants. The mobility decisions of high income households are five times more responsive to changing crime rates than those of the poor. Whites and blacks show similar responses to crime. Households with children are twice as responsive to crime as households without children.

Section IV summarizes the results of the paper and provides rough calculations of the costs of crime and crime-related mobility for cities and their residents. In addition to the direct costs of victimization, crime imposes numerous other costs on city residents. Because crime-related out-migration is concentrated among the rich, rising crime will be accompanied by increasing concentrations of poverty. While those remaining in the city are likely to have greater need for locally provided public services such as police protection, public education, public transportation, and city hospitals, the ability to provide those services is diminished. Evidence also suggests that rising crime rates are associated with declining housing prices, eroding the property tax base, which is the primary revenue source of cities. In the presence of fiscal increasing returns (Blanchard and Summers 1987), cities can be caught in a downward spiral in which rising tax rates lower real wages. To the extent that peer effects are important to human capital development (Case and Katz 1991, Benabou 1993, Cutler and Glaeser 1995) the exodus of the most mobile groups will exert a further negative externality on those left behind. 


\section{Section 1: Correlations between Changes in Crime and Changes in City Population}

We begin our analysis by specifying a simple reduced-form relationship between changes in crime and changes in city population. We include changes in both central city and suburban crime rates in the specification, along with a range of other covariates described below to capture socioeconomic, economic and demographic characteristics of the city, SMSA, and state. Our logic for focusing on changes in crime rates is that in equilibrium, the previous level of crime in a city will already have been incorporated into the individual's residential choice decision (although potentially with some adjustment lag). The theoretical prediction that changes and not levels of crime should effect changes in city population is strongly supported by the empirical evidence presented later in the paper. The basic specification we employ is as follows:

$$
\begin{aligned}
\triangle \ln \left(C I T Y_{-} P O P_{i t}\right)= & \beta_{1} \triangle C I T Y_{-} C R I M E_{i t}+\beta_{2} \triangle S U B U R B_{-} C R I M E_{i t}+\beta_{3} \text { UNEM } \\
& +\beta_{4} I N C O M E_{i t-1}+\beta_{5} \Delta \ln \left(S T A T E P O P_{i t-1}\right) \\
& +\beta_{6} \frac{o}{D B L A C K_{i t-1}}+A G E_{i t-1} \Theta+\lambda_{t}+Y_{r}+\epsilon_{i t}
\end{aligned}
$$

where the subscripts $\mathrm{l}, \mathrm{t}$, and $\mathrm{r}$ index cities, time, and regions respectively. The population variable is in log changes whereas the two crime variables are in changes in per capita rates. This specification allows the impact of changes in crime on mobility to be independent of the level of crime; other specifications such as log changes in both crime and population, or changes in levels of both variables, lead to similar results when evaluated at the sample mean. With the exception of the crime variables, which enter contemporaneously and will be instrumented, one year lags are used for all of the other covariates to reduce endogeneity problems. ${ }^{7}$ In addition to economic controls, a set of

7 It is unclear whether these covariates should enter in levels or changes. The same logic that makes changes rather than levels of crime rates appropriate suggests changes for 
variables reflecting the age distribution of the population, lagged log-changes in state populations, and a variety of indicator variables are included to capture other systematic sources of variation.

Equation (1) is estimated using a panel of data covering the years $1976-1993$ for 137 U.S. central cities with populations greater than 100,000 in 1975 . Throughout the analysis we allow for heteroskedasticity by city size. Data limitations necessitate a number of compromises because the analysis is performed at the city level. Annual data on net migration is unavailable, so changes in overall city population, which are influenced not only by migration but also by birth, death, and immigration rates, are used instead. Birth and death rates (approximately 1.5 and 0.9 per hundred) are relatively low compared to gross flows due to migration (roughly six percent of the U.S. population moves across county lines each year (Schwartz 1987)). ${ }^{8}$ Immigration rates in the United States over the time period examined are roughly 0.2 percent per year. Sampson and Wooldredge (1986), using data from the decennial census, find that their results are not sensitive to the choice of overall city population changes versus net migration flows. Our results are also robust to the use of net migration data from the Census in Section III.

The crime rates used are the per capita number of index crimes reported to the police and collected in Uniform Crime Reports. Given that less than half of all

these other variables as well. On the other hand, the demographic controls may be picking up differential levels of mobility across groups (e.g. young adults move six times as frequently as those over age 65), which suggests levels as the correct choice. The results that follow include levels. An earlier version of this paper lavailable on request from the authors) utilized changes with little effect on the crime coefficients.

B Moreover, movers affect city populations in both the community they leave and the community they move to, whereas births and deaths affect only one community. This effectively doubles the importance of migration in explaining city-level population flows. 
victimizations are reported to the police, the UCR crime data are potentially contaminated by substantial measurement error. Victimization data, however, is not available below the level of regions, necessitating the use of UCR statistics. In a previous version of this paper, we attempted to disaggregate crimes into violent and property, obtaining similar coefficients on both types. The high degree of collinearity between those two crime classifications makes it difficult to separately identify the coefficients, particularly in the IV estimates presented in Section II. Consequently we present only estimates aggregated over all crime categories in the tables; full results disaggregating crimes into violent and property are available from the authors on request. We use crime rates in the rest of the Metropolitan Statistical Area, excluding the central city, as our measure of suburban crime.

The types of covariates available in a city-level panel are less than ideal. Most citylevel data is collected only in decennial census years, necessitating a tradeoff between the level of aggregation of the data and the frequency of collection. As a general principle, we use the most disaggregated annual source of data available in our regressions. Unemployment rates are available annually by SMSA. Per capita income is available on a yearly basis at the state level. The age distribution of the population is also available annually by state. We choose to linearly interpolate the percent of a city's population that is black from decennial census data rather than using state-level data. In the OLS regressions of this section, the primary strategy adopted for minimizing the problems associated with the lack of good controls is the inclusion of numerous indicator variables: year dummies, region dummies corresponding to the nine census regions, and city-fixed effects. Because the left-hand side variable is already in differences, a city-fixed effect picks up within-city trends over time. In some cases, we replace the year and region indicators with region-year interactions to better control for regional economic and 
demographic shifts as well as possible changes over time in tastes for climate or other regional characteristics. Two further points about the lack of good control variables are also worth noting. First, in the instrumental variables estimates, as long as the omitted variables are uncorrelated with the instruments, consistent estimates of the crime parameters will nonetheless be obtained. Second, in Section III of the paper where we use individual-level data from the census and therefore have a much better set of controls, we obtain similar results whether we use the limited set of covariates utilized here or a greatly expanded set of covariates including household-level controls.

Summary statistics for the data are presented in Table 1. For those variables that enter equation (1) as changes, summary statistics for both the levels and changes are shown. OLS regression results are presented for a range of specifications in Table 2. Column 1 corresponds directly to equation (1). Column 2 adds city-fixed effects. Column 3 includes both city-fixed effects and region-year interactions. Columns 4-6 mirror the first three columns with once-lagged crime levels added to the specification.

The coefficients on the crime rate changes are in the top two rows. Including cityfixed effects and region-year interactions improves the fit of the model but has little effect on the crime variables. The crime coefficients are statistically significant in all specifications. For the purposes of interpreting the results, the change in city residents for each additional reported crime is a useful measure of the magnitude of the effect. It is straightforward to demonstrate that $\beta_{1}$ closely approximates (but slightly overstates) that measure and thus is directly interpretable. ${ }^{9}$ The interpretation of $\beta_{2}$ is more complicated,

9 The larger is the variation in crime rates relative to the variation in city populations, the closer is the approximation. In our data, the standard deviation of percent changes in year-to-year crime rates is five to six times larger than the corresponding value for city populations. 
however, because it depends on the relative sizes of the city and suburban populations. In our data, suburbs on average have three times as many residents as central cities. Thus, to determine the change in city residents per additional suburban crime at the mean of our sample, one must divide $\beta_{2}$ by three. According to the estimates, an additional city crime is associated with a decline in city population of about one resident. The coefficient on suburban crime rates translate into an impact about one-sixth as large as that for city crime rates. A one-standard deviation change in city crime rates (roughly a ten percent change in crime), translates into a decline in city population of slightly less than one percent.

The other covariates enter in a plausible manner. A percentage point change in SMSA unemployment leads to a 0.035 to 0.23 percent decline in city population. This translates into a decrease of between 5 and 35 city residents for each 100 additional persons unemployed. That estimate is similar in magnitude to the state-level estimates in Blanchard and Katz (1992). The size of the unemployment effect on city populations increases substantially when city-fixed effects are included. There is some evidence that cities located in states with higher per capita income tend to grow faster. Cities with a higher initial fraction of black residents appear to grow more slowly, mirroring the earlier findings of Frey (1979). There is little within-city variation in percent black, however, so with city-fixed effects the estimates are imprecise. The age coefficients, which are relative to the omitted category "over age $65, "$ flip sign with the inclusion of city-fixed effects. The coefficient on lagged state population growth is very large with estimated elasticities between 0.33 to 0.64 . Excluding this variable, however, has little impact on the crime parameters.

The specifications in columns 1-3 of Table 2 assume that changes in crime and population occur contemporaneously. To test the possibility of partial adjustment or lagged 
responses to crime, columns 4-6 include the once-lagged crime rate in levels. None of the lagged crime rates are statistically significant, and the magnitudes of the coefficients are generally less than a tenth as large as those associated with changes in crime rates. Lagged crime changes also appear to have weak explanatory power, as do leads of crime changes.

We have also explored numerous other variants of the basic specification (not shown in tabular form). Estimating the model using fixed effects or longer differences in place of one-year differences yields similar estimates. Dividing the sample according to time period, we cannot reject the null of equal coefficients across the two parts of the sample. Finally, splitting the sample by city size, we cannot reject the null of equality across cities greater than or less than 250,000 in population.

\section{Section II: Establishing Causality in the Relationship between City Populations and Crime} Rates

The preceding section documents a strong negative correlation between changes in crime rates and changes in city populations, but cannot provide any clear guidance about the direction of causality. While one possibility is that rising crime rates lead to urban flight, there are also a number of plausible channels through which population changes might affect crime rates. Looking cross-sectionally, crime rates are much higher in large urban areas, suggesting that increases in city population lead to higher crime rates, due perhaps to increased criminal opportunities in densely settled areas, the increased anonymity of big-city life, or because big cities attract likely criminals (e.g. Glaeser and 
Sacerdote 1996). ${ }^{10}$ If that is the case, the estimates of the previous section may understate the true causal relationship between city crime and depopulation since city growth will lead to higher crime rates.

On the other hand, there are a number of factors suggesting that the OLS estimates may overstate the true magnitude of the causal impact of city crime. First, an omitted third variable that is positively correlated with changes in crime rates and negatively correlated with city population changes could explain the negative OLS coefficient. Second, if the pool of residents in shrinking cities is increasingly comprised of less mobile groups that are also more likely to engage in criminal activity, then depopulation might be associated with increasing per capita crime rates. ${ }^{11}$ Wilson (1987) further argues for nonlinearities between concentrations of poverty and crime that would exacerbate this bias. Third, if there is measurement error in city populations, then a ratio-bias problem is present since crime rates are defined on a per capita basis. Unlike the standard regression model where measurement error in the left-hand side variable will not bias the coefficients, when the dependent variable appears in the denominator of the right-hand side variables, measurement error induces a negative bias. ${ }^{12}$ Finally, city population may be an incorrect

10 Where data are available, urban crime rates are almost always higher than rural crime rates. Beattie (1995), for instance, reports that for the period 1690-1720, prosecutions for offenses against property in the city of London were almost seven times greater than the mostly rural counties of Essex and Sussex. An apparent exception to this pattern is American cities in the late 1800 s; the emergence of the professional police force in the latter half of the 19th century appears to have dramatically reduced the amount of disorder in large American cities (Monkkonen 1981).

11 One caveat to this argument is that the rich are more likely to report crimes to the police than the poor, so even if the actual victimization rate rises due to compositional changes, the reported crime rate may not.

12 When an individual household's mobility decision is used as the dependent variable in Table 8 , ratio bias is not a concern. The results are unaffected, suggesting ratio-bias is not 
denominator for crime rates if a large fraction of the victims of crime are commuters or tourists. If many former city residents relocate to the suburbs but continue to work in the central city and be victimized there, ${ }^{13}$ this could induce a spurious negative correlation between city populations and city crime rates as measured in this paper.

We attempt to determine causality through the use of instrumental variables. In what follows, we focus our efforts on instrumenting for city crime rates, treating suburban crime rates as exogenous to city population. From a theoretical perspective, the endogeneity stories discussed above are more directly applicable and compelling for city crime rates (e.g. reverse causality and ratio bias). Empirically, we have also experimented with instrumenting for both city and suburban crime rates, with no impact on the city crime coefficients. Because of a weaker first-stage fit, we can never reject that the suburban crime coefficients are equal to zero when instrumented.

Valid instruments for the city crime variable must affect city crime rates, but not otherwise belong in the equation determining city population changes. The natural choices of such instruments are measures of the severity of the state criminal justice system, which will reduce crime either through deterrence or incapacitation, but should have little effect on city migration except via crime. The two instruments we use exploit the welldocumented crime-reducing impact of prisons. Prisoner self-reports suggest that the median prisoner commits roughly 15 index crimes a year prior to incarceration (Dilulio and Piehl 1991, Spelman 1994). Panel-data analyses using state-level aggregates, which capture not only incapacitation, but also deterrence and replacement effects, yield

a major problem here.

13 Census data on place of work suggests that roughly 80 percent of those who work in the central city continue to work there after moving residence to the suburbs. 
estimates of crime reductions per prisoner of similar magnitudes (Marvell and Moody 1994, Levitt 1996).

The particular instruments used are lagged changes in the commitment and release rates of state prison systems per reported crime in the state. Commitments include both new prison terms resulting from criminal convictions and commitments resulting from probation and parole violations. ${ }^{14}$ These variables capture both incapacitation effects and deterrence via the certainty and severity of punishment in the state. A high commitment rate implies a high likelihood of detection and conviction. A low release rate translates into a longer mean punishment per conviction.

These prison population flows include convictions for crimes other than the index crimes considered in this paper, notably drug offenses. In 1993, 22 percent of state prisoners were held on drug-related charges only, up from 6.4 percent in 1979 . The state prison data also does not include either federal prisoners or those held in local jails. Though imperfect, the instruments are still highly correlated with crime rates. The instruments are unlikely to be strongly correlated with changes in city populations, however, except through their impact on crime rates. This is particularly likely to be true since the instruments are defined at the state level rather than the city level. The average city in our sample represents only seven percent of the population and only eleven percent of the crime for the state in which it is located. ${ }^{15}$

14 When entered separately, new commitments and parole and probation-related commitments had similar coefficients in the first-stage regression and the 2SLS results were not substantially affected.

15 State prisons generally are not located in big cities which could potentially induce a negative correlation between city populations and commitment rates: when many city residents are being sent to prison, the removal of those offenders will reduce city populations. Our reduced form estimates, however, find that commitment rates and city 
One potential problem with the instruments selected is the fact that they are denominated by crime rates (albeit state crime rates) while they are also instrumenting for crime rates. In the absence of measurement error, the presence of crimes in the denominator of the instrument does not result in any contamination of the instrument if the functional form is correctly specified. With measurement error in reported crime rates, however, ratio bias arises. There are two important points to note on this topic. First, the instruments are constructed using state-level rather than city-level data and individual cities generally represent a small fraction of state crime. Nonetheless, we attempt to lessen this source of bias by using only lagged values of the instruments. Second, ratio bias will exaggerate the negative relationship between commitments and the crime rate in the firststage regression while the effect of releases will be systematically understated. Empirically, however, we find that commitments and releases carry coefficients of similar magnitude.

Columns 1-3 of Table 3 present the first-stage estimates using the same sets of covariates used in the previous section. In all cases, the instruments enter with the expected sign: a higher rate of prison commitments reduces crime whereas more releases are accompanied by crime increases. As reported in the bottom panel of the table, the prison variables are jointly significant at the .01 level for all of the crime regressions. Releases and commitments have similar effects. A one-percentage point increase in the prison commitment or release rate per crime shifts city crime by roughly six percent over a two-year period. The demographic and economic variables included in the regressions are generally not strong predictors of crime rates having controlled for the other factors.

populations are positively correlated, implying that this source of bias cannot explain our results. 
If prison commitments and releases are valid instruments for crime rates and there is a negative causal link between crime and city populations, a reduced form regression of city population on the instrumental variables should yield coefficients that are opposite in sign to those obtained in the first-stage regressions. Columns 4 to 6 of Table 3 present such estimates. As predicted, each of the instruments enters with the opposite sign observed in the first three columns. The prison variables are jointly significant at the .05 level. As in the first stage, the magnitude of the coefficients on commitments and releases are comparable.

Table 4 presents the two-stage least squares estimates treating city crime rates as endogenous and instrumenting with the once- and twice-lagged changes in commitments and releases. The coefficients on city crime that we obtain are slightly more negative in each case than the corresponding OLS coefficient in Table 2. Although the standard errors rise substantially, the estimates are statistically different from zero at the .05 level. Each additional city crime results in roughly a 1.3 to 2.0 person reduction in population, compared to estimates of approximately 1.1 from OLS. The larger 2 SLS estimates suggest that any bias in the OLS estimates resulting from omitted variables or compositional changes in city populations is overwhelmed by the natural tendency for large cities to have higher crime rates. Our results cast some doubt on the arguments of Wilson (1987) which suggest that declining city populations "cause" crime rather than vice-versa. A onestandard deviation increase in city crime rates translates into a decline in city population of between one and two percent. ${ }^{16}$ The other covariates, which are treated as exogenous,

16 If there are lagged variables that are omitted from the specification, but are correlated with the instruments (which are lagged) and contemporaneous crime and population changes, the variation from these omitted factors will mistakenly be attributed to our instruments potentially biasing the 2SLS estimates. To test this hypothesis, we 
carry coefficients similar to those reported in the OLS specifications.

P-values from an $N^{*} R^{2}$ test of the overidentifying restrictions are reported in the bottom panel of the table. In all three cases, the overidentifying restrictions are near the .05 level of statistical significance. One possible reason for the relatively poor performance of the overidentifying restrictions is the inclusion of cities in our sample that represent a non-negligible fraction of the state's population. For such cities, the arguments made earlier for the exogeneity of the instruments are less persuasive. To test this hypothesis, columns 4 and 5 of Table 4 break the sample according to whether a city has more or less than four percent of the state's total population. The overidentifying restrictions pass with ease in column 4 , but are rejected at the .05 level in column 5 . This lends credence to the argument that the exogeneity of the instruments is suspect for cities that are large relative to the state. Comparing the coefficients on city crime in columns 4 and 5 , the estimated impact of crime is larger in the cities that are a small fraction of their state. This pattern is not apparent in OLS estimates, where the city crime coefficients are actually slightly smaller for cities that are less than four percent of the state population (-1.12 vs. -1.19$)$. The larger parameter estimates in column 4, for which the exogeneity of the instruments is more likely, suggest that, if anything, the coefficients reported in columns 1-3 are biased towards zero because of the inclusion of cities of all sizes.

Section III: Using Census Data to Identify Differential Effects of Crime on Migration by Income Group and Race

estimated Table 4 including the once-lagged dependent variable as a right-hand side variable to capture such omitted factors. The results obtained are almost identical to those presented in the table. 
Because the results up to this point are derived from aggregate population data, it has been impossible to isolate differential impacts among sub-groups of the population. In this section, we perform two types of analysis using mobility information from the 1980 Census of Population and Housing to investigate crime-related migration patterns by income group and race. Since we only have a cross-section of 81 cities, we limit our analysis to OLS. The first approach aggregates the individual-level data to the city level and estimates regressions that are similar to the preceding section, but for sub-groups of the population. The second approach employs the migration decisions of individual households as the dependent variable (as opposed to city-level aggregates). The advantages of the latter analysis are that it makes it possible to control for individual household characteristics and that it eliminates ratio-bias concerns.

\section{Analyzing Census Data Aggregated to the City Level}

The data used are from the PUMS 5 percent sample of the 1980 census, aggregated to the city-level. Only half of the observations in the PUMS data were also included in the mobility sample, leaving usable data for 2.5 percent of the U.S. population. We are able to identify movers in and out of 90 of the 137 cities analyzed in the preceding section. In the remaining 47 cities, central cities and surrounding areas are not separately identified in the PUMS data. Of those 90 cities, 9 are missing data on one or more covariates, leaving 81 cities in our sample.

To construct the net migration data, we compare the place of residence of the household head in 1975 and 1980 . Households are divided into three migration categories: stayers, comers, and goers. Households that do not move or change addresses but remain within city limits are categorized as stayers. Those who arrive in a city or leave the city 
are classified as comers or goers respectively. In some of the analysis, we further divide comers and goers according to whether their change of residence is within or across SMSAs. Households are also grouped according to total household income from all sources in 1979. Households with income below $\$ 10,000$ in 1979 dollars (roughly $\$ 20,000$ in 1993 dollars) are classified as "low" income. Households with 1979 income between $\$ 10,000$ and $\$ 30,000(\$ 20,000-\$ 60,000$ in 1993 dollars) are labeled "middle" income. Households with income above that level are considered "high" income. Approximately 30 percent of the households fall into the low income category, 50 percent are middle income, and the remaining 20 percent are high income. Because we only have 1979 income, we are unable to classify households according to their initial 1975 incomes or to examine within-household changes in income between 1975 and $1979 .{ }^{17}$

For each of the 81 cities for which we have data, the fraction of stayers, comers and goers is computed by income group, using 1975 city population within the income category as the denominator. We have an average of 5,856 household observations per city, with over 1,000 observations for the smallest cities in our sample. Summary statistics on migration patterns are presented in Table 5. Overall, net migration (comers minus goers as a fraction of 1975 population) for the five year period is approximately -8 percent. ${ }^{18}$ Net migration rates were larger for high income households (-16.8 percent) and

17 Given the possible endogeneity of 1979 income, we have also examined mobility classifying households by educational attainment, obtaining similar patterns.

18 This number is greater than the observed 3 percent aggregate decline in city populations for the cities in our sample over the period 1975-1980. Most of that gap can be explained by differences in birth and death rates. Annual national birth rates (per 100 population) were approximately 1.5 in this time period; comparable death rate statistics were roughly 0.9 . Assuming that the same rates apply to these cities, the differential between birth and death rates accounts for a three percentage point gap between city population changes and net migration. Overall, the correlation between city population 
actually positive for low income households $(0.5$ percent). Blacks flowed into cities on net, while the non-black population declined by 10 percent. Roughly 30 percent of households residing in one of these central cities in 1975 had left that city by 1980 , with low income households less likely to leave. New arrivals to cities offset three-quarters of these leavers, with high income households less likely to come to cities. 60 percent of city out-migrants left the SMSA; over 70 percent of the new arrivals to central cities came from outside the SMSA.

OLS estimates of the relationship between changes in city net-migration rates and changes in crime rates are presented in Table 6. In addition to using a cross-section rather than a panel of data, the specifications shown in Table 6 differ from earlier estimates in that five-year rather than one-year changes in crime rates are used (since only five-year changes in place of residence are available). A richer set of covariates is available in census years. Therefore, in addition to all the variables used in the previous section, the specifications in Table 6 add the fraction of city residents completing high school, percent in owner-occupied housing, percent employed in the manufacturing sector, mean hourly manufacturing wage, city median family income, percent of housing units that are multifamily, mean temperature in January, and mean annual precipitation. All of these variables are available in the City and County Data Books published by the U.S. Census. The 1970 value of the census covariates are used as controls in Table 6 . Using changes between 1970 and 1980 or the 1980 levels did not materially affect the crime coefficients.

Column 1 of Table 6 presents the estimates for all cities and income groups combined. The coefficient on city crime, -1.39 , is consistent with the estimates of the changes and net-migration in our sample is 0.45 . 
preceding two sections and is statistically significant at the .10 level. Suburban crime changes, while carrying the same sign as previously, are imprecisely estimated. High median family income in a city is a statistically significant predictor of city population growth, as are high January temperatures and low rainfall. The other covariates are not statistically significantly different from zero.

Columns 2-4 provide separate estimates of net migration by income group. High income households are most responsive to city crime rates with a coefficient of -2.58 . The net migration response of low income households is less than one-fifth as great. Middleincome households have an intermediate response. When the three specifications in columns 2-4 are estimated jointly we reject the equality of the crime coefficients across high and low income groups at the .05 level. A one standard deviation change in city crime over the five-year period $(0.0165$ crimes per capita) is associated with a 4.3 percent decline in high-income households, a 2.0 percent fall in middle-income households, and a 0.8 percent decrease among the poor. Columns 5 and 6 divide the sample on racial lines, with no apparent difference across races. The last two columns compare families with and without children. Families with children are almost three times as responsive to city crime rates. While the suburban crime coefficients are imprecisely estimated, it appears that families with children are also more responsive to suburban crime rates. ${ }^{19}$

Because the number of variables is large relative to the number of observations in the specifications in Table 6, we also present the city crime coefficient from specifications including only the crime variables and region dummies in the bottom panel of the table as a test of the sensitivity of our results to the inclusion of control variables. The estimates are

19 For a more detailed treatment of the influences of children on locational choice, see Glendon (1996). 
similar in all cases.

Further patterns are revealed by decomposing the net migration effects according to comers and goers, and by whether moves cross SMSA lines. This breakdown is presented in Table 7 for city crime rates. The columns in Table 7 correspond to the categories in the previous table. In each case, the first row redisplays the coefficient on city crime rates from Table 6, which is then decomposed in the subsequent rows. The coefficient on goers (row 5) minus the coefficient on comers (row 2) equals the total crime-related impact on net-migration (row 1). Within comers and goers, we further decompose the effect by whether the migration is within or across SMSAs.

Almost all of the crime-related impact on mobility arises from increased outmigration, as evidenced by the large magnitudes on goers compared to comers. One possible explanation for this patterns is that current residents are better informed about recent changes in crime than are potential in-migrants. Comparing the bottom two rows of Table 7, those leaving cities due to crime remain in the SMSA 70 percent of the time overall (less frequently for the rich, more frequently for blacks and families with children). In contrast, for all out-migrants (including those who move for reasons other than crime), 40 percent remain in the SMSA.

Analyzing Individual Household Mobility Decisions using Census Data

Focusing on individual household mobility decisions rather than city-level aggregates has two advantages. First, it allows the inclusion of household characteristics as covariates. Second, it eliminates concerns over ratio-bias since measurement error in city population does not affect the dependent variable. The primary difficulty associated with performing a household-level analysis are the computational costs. For example, to avoid 
sample selection bias when estimating the decision of whether or not to move into a particular city, one must include all households in the sample in the estimation, even though only a trivial fraction of the total households actually move into the city.

We use the results of the preceding city-level analysis to guide our specification choices in reducing the computational burdens to a manageable level. Table 7 demonstrates that almost all of the crime-related net migration from cities is due to increased outflows of residents. Therefore, in the following analysis we focus exclusively on the decision of current city residents about whether to stay or leave. Doing so limits the sample to residents of large cities in 1975 , approximately 400,000 observations, or roughly $15 \%$ of the 1980 PUMS mobility sample.

The results of the individual-level analysis are presented in Tables $8 \mathrm{a}$ and $8 \mathrm{~b}$. For simplicity of interpretation, we present estimates from linear probability models where the dependent variable is equal to one if a household residing in one of the large central cities in our sample in 1975 remains in that city through 1980, and zero if the household leaves the central city before 1980 . As before, the five-year change in the per capita reported crime rate captures the effect of crime. Probit and logit yield similar marginal effects when evaluated at the sample means. ${ }^{20}$ All specifications in Tables $8 \mathrm{a}$ and $8 \mathrm{~b}$ include the full set of city, state, and region controls that were used in Tables 6 and 7 . With the exception of the first column, the regressions also include a wide array of household-level controls: income indicators (high, middle, and low), the age, sex, race, years of education, and marital status of the household head, and whether the household head is a homeowner, in

20 We have also experimented with multinomial logit models that allow for differential effects for those households moving within and across SMSAs. These results suggest that crime has a larger effect on those moving within the SMSA as would be expected. 
the armed forces in 1975, or attends college in 1975 . We account for correlation in the error term for households in a given city so as not to understate the standard errors. Failing to account for within-city correlations leads to standard error estimates that are roughly twenty times too small on the crime coefficients. Because all of the variation in the crime variable is at the city level, there is actually very little information gain in moving from city-level aggregates to individual-level estimation, as reflected in the fact that the standard errors in Tables 7 and 8 are not very different. For comparison purposes, we report the corresponding coefficient from the city-level regressions in the bottom panel of Table 8.

Column 1 of Table 8 a includes only aggregate controls for the full sample of households. Each additional reported crime is associated with 1.61 residents leaving the city. In contrast to Table 6 , there is some evidence that suburban crime rates matter here. This difference is consistent with suburban crime rates having two offsetting effects on city population. The first effect is to increase city population by reducing the outflow of city residents to the suburbs. The second effect is to discourage those outside the SMSA from moving into the SMSA, depressing city population. The net migration regressions in Table 6 capture both of these effects, whereas Table 8, which looks only at the decision on city residents to stay or go, reflects only the former.

The household-level estimate of the impact of city crime in column 1 of Table 8 is indistinguishable from the comparable value from the aggregated regression in the bottom panel of the table. Since the aggregated regression potentially suffer from ratio-bias, but the individual-level regressions do not, the similarity of the two sets of estimates suggests that ratio-bias cannot account for the observed negative relationship between crime rate changes and population changes. 
Column 2 of Table $8 \mathrm{a}$ is identical to column 1 except that a full complement of household-level controls are added to the specification. It is interesting to note that while these variables significantly improve the $\mathrm{R}^{2}$ of the regression, the estimated impact of crime is little changed. This increases our level of confidence in the earlier estimates using citylevel aggregates, where there was concern that the set of controls was incomplete. Having controlled for city-level characteristics household heads who are young, male, black, have children, are single, or have lower educational attainment are more likely to stay in central cities. Members of the military and those attending college are far more likely to leave the city. The only surprise among the coefficients, is that having controlled for these other factors, the rich are somewhat more likely to remain in cities.

The last three columns of Table 8 a divide the sample according to household income. High income households are more sensitive to crime, but the differences are muted compared to Table 6 . The other covariates tend to carry similar coefficients across income groups. The first two columns of Table $8 \mathrm{~b}$ divide the sample between blacks and non-blacks. As before, little differential effect of crime is observed across races. The most interesting difference between blacks and non-blacks is the effect of income. Among nonblacks, high income is associated with remaining in central cities, controlling for other factors. With blacks, there is no such effect. The final two columns of Table $8 \mathrm{~b}$ split the sample into households with and without children. Households with children are substantially more likely to leave central cities in response to rising crime. High income families with children are somewhat more likely to leave cities than low income families with children, whereas the opposite is true of households without children.

\section{Section IV: Conclusions}


This paper examines the connection between crime, urban flight, and central city decline. Rising city crime rates appear to play a causal role in city depopulation. Each reported city crime is associated with approximately a one person decline in city residents. There is some evidence that rising crime rates in the suburbs tend to keep people in cities. Instrumenting using measures of criminal justice system severity yields slightly larger estimates than OLS. Almost all of the impact of crime on falling city population is due to increased out-migration rather than a decrease in new arrivals. Migration decisions of highincome households are much more responsive to changes in crime rates than those of the poor. Households with children are also more responsive to crime. Crime-related outmigrants are much more likely to stay within the SMSA than those leaving the city for other reasons.

Increases in crime rates and the subsequent exodus from the city impose a number of costs on those city residents who remain behind. The most obvious cost to city residents is the direct costs of increased crime victimization. Over the last twenty years, the quartile of cities with the greatest increase in crime saw per capita crime roughly double from 0.065 reported crimes per capita to 0.127 ; crime rates were essentially unchanged for cities in the bottom quartile $(0.069$ in 1973 to 0.074 in 1993). Cohen (1988) and Miller, Cohen, and Rossman (1993) estimate victim costs per crime, incorporating out-of-pocket costs, physical and psychological damages, lost productivity, and lost life. Valuing a lost life at $\$ 2.7$ million, the typical crime reported in large cities in 1993 has victim costs of $\$ 10,200$ associated with it. ${ }^{21}$ The difference in crime increases

21 The total estimated costs of crime are sensitive to the value assigned to a human life. If the value of a human life is assumed to be $\$ 1.0$ million dollars, the cost per crime falls to $\$ 6,100$. 
between top and bottom quartile cities translate into almost $\$ 600$ per person per year. Since the estimated crime gap between the two sets of cities includes only those crimes reported to the police, the true difference in costs may be even greater.

In addition to the direct costs of crime, crime-related migration imposes further costs on cities. Decreased city population decreases the demand for housing, causing declines in property values. Blanchard and Katz (1992) find the short-run (1-5 year) elasticity of housing value with respect to employment levels of approximately two and a long run (10 year) elasticity close to zero. Assuming declines in population and employment have similar effects and taking an elasticity intermediate between those two estimates, the crime-related migration differential between top and bottom quartile cities ( 7 percent of the city population) translates into a $\$ 5,500$ decline in median housing values in high versus low quartile cities. Property values will also decrease if the disamenity of crime is capitalized into housing values (Smith 1978, Thaler 1978, and Hellman and Naroff 1979) -- an additional $\$ 16,000$ if the direct costs of crime computed above are fully capitalized. $^{22}$

Because crime-related mobility is concentrated among the rich, crime will increase concentrations of poverty in central cities, although the effects do not appear to be particularly large. In 1975, roughly 30 percent of central city residents fell into our low income category, 50 percent were classified as middle income and the remaining 20 percent were high income. Using our estimates of net-migration by income group in Table 6 , the increases in crime in the top quartile cities by 1993 would have caused the fraction

22 Declining housing values due to capitalization of the disamenity do not entail an additional cost to city residents, but rather are a reflection of the direct costs of victimization cited above. 
of high income residents to fall to 18.2 percent and the fraction of low income residents to rise to 31.6 percent. While it is unlikely that the real economic effects of a change of this magnitude could be substantively large, it is possible that the decline in the number of rich households imposes negative externalities on those who remain in the central city. To the extent that peer effects are important to human capital development (Case and Katz 1991, Benabou 1993, Cutler and Glaeser 1995), the exodus of skilled residents hurts those who stay.

Fiscal stress on city government is likely to be linked to rising crime and differential mobility patterns. Low-income residents will have greater need for locally-provided public services such as police protection, public education, public transportation, and city hospitals. In particular, high and rising crime rates are associated with increases in future spending on police. Using panel-data from the 59 largest U.S. cities, we estimate that the crime difference between top and bottom quartile cities translates into an additional $\$ 30$ per capita annually in police expenditure. ${ }^{23}$ The poor are also less likely to be covered by private health insurance. Public education costs are greater for low-income children, who are disproportionately represented in special educational programs. ${ }^{24}$ Combining the

23 These estimates are obtained from city finance data for the years 1976,1981 , 1986, and 1991. We regress the five-year lead change in police expenditure per capita on either the current crime rate, the five-year lagged change in crime, or both. We include the same covariates as in Section II of the paper. When entered separately, the coefficient on crimes per capita is 648 (SE $=225$ ) and the coefficient on five-year lagged changes in crime per capita is $696(S E=262)$. When both the level and changes in crime are included in the same regression, both enter positively. The two coefficients are jointly, but not individually, statistically significant. Full regression results are available from the authors on request.

${ }^{24}$ Crime also carries with it large costs for courts, jails, and, prisons, but these are generally not borne by cities.

If there are increasing returns to scale in goods and services provided by city governments, declining populations lead to inefficiencies in producing such goods. 
estimated declines in housing value due to crime with the increased levels of police expenditure, for a fixed effective property tax rate, the impact of differential crime rates between top and bottom quartile cities translates into roughly $40 \%$ of the mean city's property tax revenue. ${ }^{25}$ In comparison, municipalities in Massachusetts anticipated losing about 14 percent of total tax revenue after the passage of Proposition 2 1/2 (Ladd and Wilson 1983), and property tax revenues fell by 50 percent in California after implementation of Proposition 13.

Empirical evidence, however, suggests that the production of these goods is characterized by roughly constant returns to scale (Bergstrom and Goodman 1973, Gonzalez and Mehay 1987).

25 Crime is also likely to reduce other sources of city revenues, such as sales taxes and income taxes, on a per capita basis. The fact that most of the crime-related movers remain within the SMSA suggests that many will continue to work in the central city. Consequently, the tax losses through these other channels is likely to be smaller proportionately than via property taxes. Also, to the extent that state governments increase aid to cities experiencing fiscal stress (Yinger and Ladd 1989), this figure may overstate the true costs borne by city residents. 
Table 1: Summary Statistics for Panel Data, 1976-1993

\begin{tabular}{|c|c|c|c|c|}
\hline Variable & Mean & Std. Dev. & Minimum & Maximum \\
\hline City Population & 392986 & 727,406 & 94,320 & $7,530,493$ \\
\hline City Crime Per Capita & .090 & .025 & .037 & .207 \\
\hline $\begin{array}{l}\text { Suburban Crime } \\
\text { Per Capita }\end{array}$ & .047 & .015 & .013 & .125 \\
\hline $\begin{array}{l}\text { SMSA Unemployment } \\
\text { Rate }\end{array}$ & .066 & .025 & .015 & .208 \\
\hline $\begin{array}{l}\text { State Real Income Per } \\
\text { Capita }\end{array}$ & 18,521 & 2,916 & 11,028 & 29,159 \\
\hline$\%$ Black & .229 & .174 & .004 & .836 \\
\hline \multicolumn{5}{|l|}{ State Age Distribution: } \\
\hline $0-17$ years & .272 & .025 & .197 & .375 \\
\hline $18-24$ years & .121 & .013 & .085 & .154 \\
\hline $25-44$ years & .300 & .029 & .233 & .364 \\
\hline $45-64$ years & .190 & .013 & .139 & .231 \\
\hline 65 years and up & .117 & .020 & .075 & .186 \\
\hline $\begin{array}{l}\text { State Prison } \\
\text { Commitments/ } \\
\text { Reported Crime }\end{array}$ & .022 & .012 & .004 & .087 \\
\hline $\begin{array}{l}\text { State Prison Releases/ } \\
\text { Reported Crime }\end{array}$ & .019 & .011 & .001 & .082 \\
\hline$\Delta \ln ($ City Population) & .004 & .032 & -.169 & .265 \\
\hline $\begin{array}{l}\Delta \text { (City Crime Per } \\
\text { Capita) }\end{array}$ & .0006 & .0084 & -.0471 & .0540 \\
\hline $\begin{array}{l}\Delta \text { (Suburban Crime Per } \\
\text { Capita) }\end{array}$ & -.0001 & .0056 & -.0280 & .1377 \\
\hline $\begin{array}{l}\Delta \text { Prison Commitment } \\
\text { Rate }\end{array}$ & .0012 & .0030 & -.0132 & .0283 \\
\hline$\Delta$ Prison Release Rate & .0011 & .0036 & -.0301 & .0213 \\
\hline
\end{tabular}


Notes to Table 1: Sample is comprised of annual observations from 1976-1993 for 137 U.S. central cities with population greater than 100,000 in population in 1975 . Due to occasional missing data, number of observations is equal to 2,165 . Prison commitment and release data are defined at the state level and are changes in rates per reported crime. All other data are defined at the city level unless otherwise noted. All variables are available annually except \% high school graduates, \% home-owners, \% manufacturing, and $\%$ black, which are available only in census years. \% black is linearly interpolated between decennial census years. 
Table 2: OLS Estimates of the Relationship Between City Population and Crime Rate

\begin{tabular}{|c|c|c|c|c|c|c|}
\hline Variable & (1) & (2) & (3) & (4) & (5) & (6) \\
\hline $\begin{array}{l}\Delta \text { (Per Capita } \\
\text { City Crime) }\end{array}$ & $\begin{array}{r}-1.039 \\
(.076)\end{array}$ & $\begin{array}{r}-1.035 \\
(.075)\end{array}$ & $\begin{array}{l}-1.135 \\
(.0786)\end{array}$ & $\begin{array}{l}-.992 \\
(.078)\end{array}$ & $\begin{array}{r}-1.024 \\
(.082)\end{array}$ & $\begin{array}{r}-1.123 \\
(.086)\end{array}$ \\
\hline $\begin{array}{l}\Delta \text { (Per Capita } \\
\text { Suburban Crime) }\end{array}$ & $\begin{array}{l}.539 \\
(.104)\end{array}$ & $\begin{array}{l}.525 \\
(.104)\end{array}$ & $\begin{array}{l}.424 \\
(.105)\end{array}$ & $\begin{array}{c}.448 \\
(.108)\end{array}$ & $\begin{array}{l}.499 \\
(.121)\end{array}$ & $\begin{array}{l}.440 \\
(.124)\end{array}$ \\
\hline $\begin{array}{l}\text { Per Capita City } \\
\text { Crime }(-1)\end{array}$ & ---- & ---- & --- & $\begin{array}{l}.002 \\
(.032)\end{array}$ & $\begin{array}{l}-.058 \\
(.066)\end{array}$ & $\begin{array}{l}-.052 \\
(.069)\end{array}$ \\
\hline $\begin{array}{l}\text { Per Capita } \\
\text { Suburban Crime (-1) }\end{array}$ & $\cdots$ & $-\cdots$ & --- & $\begin{array}{l}-.046 \\
(.056)\end{array}$ & $\begin{array}{l}.082 \\
(.127)\end{array}$ & $\begin{array}{l}.148 \\
(.134)\end{array}$ \\
\hline $\begin{array}{l}\text { Unemployment Rate } \\
(-1)\end{array}$ & $\begin{array}{l}-.045 \\
(.032)\end{array}$ & $\begin{array}{l}-.139 \\
(.050)\end{array}$ & $\begin{array}{l}-.228 \\
(.058)\end{array}$ & $\begin{array}{l}-.046 \\
(.032)\end{array}$ & $\begin{array}{l}-.146 \\
(.050)\end{array}$ & $\begin{array}{l}-.232 \\
(.062)\end{array}$ \\
\hline $\begin{array}{l}\text { State Per Capita } \\
\text { Income }{ }^{*} 10^{6}(-1)\end{array}$ & $\begin{array}{l}.11 \\
(.57)\end{array}$ & $\begin{array}{c}.43 \\
(1.28)\end{array}$ & $\begin{array}{c}.38 \\
(2.48)\end{array}$ & $\begin{array}{l}.24 \\
(.58)\end{array}$ & $\begin{array}{c}.48 \\
(1.30)\end{array}$ & $\begin{array}{c}.64 \\
(2.54)\end{array}$ \\
\hline$\%$ black $(-1)$ & $\begin{array}{l}-.034 \\
(.004)\end{array}$ & $\begin{array}{l}.028 \\
(.039)\end{array}$ & $\begin{array}{l}-.019 \\
(.042)\end{array}$ & $\begin{array}{l}-.033 \\
(.005)\end{array}$ & $\begin{array}{l}.039 \\
(.039)\end{array}$ & $\begin{array}{l}-.014 \\
(.043)\end{array}$ \\
\hline$\%$ aged $0-17(-1)$ & $\begin{array}{l}-.031 \\
(.085)\end{array}$ & $\begin{array}{l}-.594 \\
(.177)\end{array}$ & $\begin{array}{l}-.193 \\
(.280)\end{array}$ & $\begin{array}{l}-.046 \\
(.086)\end{array}$ & $\begin{array}{c}-.574 \\
(.180)\end{array}$ & $\begin{array}{l}-.107 \\
(.283)\end{array}$ \\
\hline$\%$ aged $18-24(-1)$ & $\begin{array}{l}.568 \\
(.127)\end{array}$ & $\begin{array}{l}-.668 \\
(.286)\end{array}$ & $\begin{array}{l}-.285 \\
(.396)\end{array}$ & $\begin{array}{l}.504 \\
(.133)\end{array}$ & $\begin{array}{l}-.723 \\
(.295)\end{array}$ & $\begin{array}{l}-.416 \\
(.401)\end{array}$ \\
\hline$\%$ aged $25-44(-1)$ & $\begin{array}{l}-.045 \\
(.076)\end{array}$ & $\begin{array}{l}-.952 \\
(.260)\end{array}$ & $\begin{array}{l}-.704 \\
(.362)\end{array}$ & $\begin{array}{l}-.086 \\
(.078)\end{array}$ & $\begin{array}{l}-.949 \\
(.267)\end{array}$ & $\begin{array}{l}-.689 \\
(.369)\end{array}$ \\
\hline$\%$ aged $45-64(-1)$ & $\begin{array}{c}.207 \\
(.151)\end{array}$ & $\begin{array}{l}-.601 \\
(.242)\end{array}$ & $\begin{array}{l}-.073 \\
(.410)\end{array}$ & $\begin{array}{l}.167 \\
(.154)\end{array}$ & $\begin{array}{l}-.631 \\
(.257)\end{array}$ & $\begin{array}{l}.023 \\
(.418)\end{array}$ \\
\hline $\begin{array}{l}\% \Delta \text { state population } \\
(-1)\end{array}$ & $\begin{array}{r}.543 \\
(.096) \\
\end{array}$ & $\begin{array}{l}.634 \\
(.124) \\
\end{array}$ & $\begin{array}{l}.356 \\
(.191) \\
\end{array}$ & $\begin{array}{c}.560 \\
(.097) \\
\end{array}$ & $\begin{array}{l}.644 \\
(.129) \\
\end{array}$ & $\begin{array}{r}.334 \\
(.194) \\
\end{array}$ \\
\hline City Fixed Effects? & No & Yes & Yes & No & Yes & Yes \\
\hline $\begin{array}{l}\text { Region-year } \\
\text { interactions }\end{array}$ & No & No & Yes & No & No & Yes \\
\hline R-squared & .310 & .390 & .490 & .315 & .393 & .495 \\
\hline
\end{tabular}

Notes: Dependent variable is $\Delta \ln$ (city population). Sample is comprised of annual observations from 1976-1993 for 137 U.S. central cities with population greater than 100,000 in population in 1975 . Number of observations is equal to 2,165 in all columns. Year and region dummies are included in all columns except those where region-year interactions are present. All variables are available annually, except for \% black, which is linearly interpolated between decennial census years. See Table 1 for further information about the level of geographic disaggregation of the covariates. Estimates control for heteroskedasticity by city size. Standard errors in parentheses. 
Table 3: First-stage and Reduced-form Estimates of State Prison Commitments and Releases on Crime Rates and City Populations

\begin{tabular}{|c|c|c|c|c|c|c|}
\hline \multirow[b]{2}{*}{ Variable } & \multicolumn{3}{|c|}{$\Delta$ per capita city crime } & \multicolumn{3}{|c|}{$\% \Delta$ city population } \\
\hline & (1) & (2) & (3) & (4) & (5) & (6) \\
\hline $\begin{array}{l}\Delta \text { Prison } \\
\text { Commitments Per } \\
\text { Crime }(-1)\end{array}$ & $\begin{array}{l}-.405 \\
(.085)\end{array}$ & $\begin{array}{l}-.393 \\
(.087)\end{array}$ & $\begin{array}{l}-.283 \\
(.108)\end{array}$ & $\begin{array}{l}.457 \\
(.300)\end{array}$ & $\begin{array}{l}.317 \\
(.295)\end{array}$ & $\begin{array}{l}.274 \\
(.368)\end{array}$ \\
\hline $\begin{array}{l}\Delta \text { Prison } \\
\text { Commitments Per } \\
\text { Crime }(-2)\end{array}$ & $\begin{array}{l}-.192 \\
(.095)\end{array}$ & $\begin{array}{l}-.173 \\
(.097)\end{array}$ & $\begin{array}{l}-.027 \\
(.117)\end{array}$ & $\begin{array}{c}.988 \\
(.336)\end{array}$ & $\begin{array}{l}.945 \\
(.330)\end{array}$ & $\begin{array}{l}.999 \\
(.404)\end{array}$ \\
\hline $\begin{array}{l}\Delta \text { Prison Releases } \\
\text { Per Crime }(-1)\end{array}$ & $\begin{array}{l}.413 \\
(.076)\end{array}$ & $\begin{array}{l}.407 \\
(.078)\end{array}$ & $\begin{array}{l}.282 \\
(.090)\end{array}$ & $\begin{array}{l}-.689 \\
(.270)\end{array}$ & $\begin{array}{l}-.742 \\
(.264)\end{array}$ & $\begin{array}{l}-.703 \\
(.312)\end{array}$ \\
\hline $\begin{array}{l}\Delta \text { Prison Releases } \\
\text { Per Crime }(-2)\end{array}$ & $\begin{array}{l}.303 \\
(.014)\end{array}$ & $\begin{array}{l}.300 \\
(.076)\end{array}$ & $\begin{array}{l}.157 \\
(.091)\end{array}$ & $\begin{array}{l}-.464 \\
(.262)\end{array}$ & $\begin{array}{l}-.544 \\
(.256)\end{array}$ & $\begin{array}{l}-.857 \\
(.311)\end{array}$ \\
\hline $\begin{array}{l}\text { Unemployment } \\
\text { Rate }^{*} 100(-1)\end{array}$ & $\begin{array}{l}-.003 \\
(.009)\end{array}$ & $\begin{array}{l}-.008 \\
(.014)\end{array}$ & $\begin{array}{l}-.052 \\
(.017)\end{array}$ & $\begin{array}{l}-.041 \\
(.032)\end{array}$ & $\begin{array}{l}-.129 \\
(.048)\end{array}$ & $\begin{array}{l}-.187 \\
(.061)\end{array}$ \\
\hline $\begin{array}{l}\text { State Per Capita } \\
\text { Income }{ }^{*} 10^{6}(-1)\end{array}$ & $\begin{array}{l}.23 \\
(.16)\end{array}$ & $\begin{array}{l}.66 \\
(.36)\end{array}$ & $\begin{array}{l}.06 \\
(.07)\end{array}$ & $\begin{array}{l}-.14 \\
(.55)\end{array}$ & $\begin{array}{l}.34 \\
(1.20)\end{array}$ & $\begin{array}{l}-1.95 \\
(2.36)\end{array}$ \\
\hline$\%$ black $(-1)$ & $\begin{array}{l}.003 \\
(.001)\end{array}$ & $\begin{array}{l}.010 \\
(.011)\end{array}$ & $\begin{array}{l}.001 \\
(.012)\end{array}$ & $\begin{array}{l}-.035 \\
(.004)\end{array}$ & $\begin{array}{l}.034 \\
(.037)\end{array}$ & $\begin{array}{l}-.005 \\
(.039)\end{array}$ \\
\hline$\%$ aged $0-17(-1)$ & $\begin{array}{l}.007 \\
(.023)\end{array}$ & $\begin{array}{l}.009 \\
(.051)\end{array}$ & $\begin{array}{l}-.044 \\
(.076)\end{array}$ & $\begin{array}{l}-.025 \\
(.083)\end{array}$ & $\begin{array}{l}-.546 \\
(.171)\end{array}$ & $\begin{array}{l}-.284 \\
(.267)\end{array}$ \\
\hline$\%$ aged $18-24(-1)$ & $\begin{array}{l}-.057 \\
(.036)\end{array}$ & $\begin{array}{l}-.119 \\
(.084)\end{array}$ & $\begin{array}{l}-.019 \\
(.111)\end{array}$ & $\begin{array}{c}.601 \\
(.126)\end{array}$ & $\begin{array}{l}-.577 \\
(.283)\end{array}$ & $\begin{array}{l}-.278 \\
(.390)\end{array}$ \\
\hline$\%$ aged $25-44(-1)$ & $\begin{array}{l}-.038 \\
(.021)\end{array}$ & $\begin{array}{l}-.073 \\
(.077)\end{array}$ & $\begin{array}{l}-.091 \\
(.101)\end{array}$ & $\begin{array}{c}.013 \\
(.074)\end{array}$ & $\begin{array}{l}-.742 \\
(.258)\end{array}$ & $\begin{array}{l}-.391 \\
(.353)\end{array}$ \\
\hline$\%$ aged $45-64(-1)$ & $\begin{array}{l}-.016 \\
(.042)\end{array}$ & $\begin{array}{l}-.020 \\
(.070)\end{array}$ & $\begin{array}{l}-.360 \\
(.110)\end{array}$ & $\begin{array}{c}.236 \\
(.147)\end{array}$ & $\begin{array}{l}-.486 \\
(.239)\end{array}$ & $\begin{array}{l}.519 \\
(.386)\end{array}$ \\
\hline $\begin{array}{l}\% \Delta \text { state population } \\
(-1)\end{array}$ & $\begin{array}{l}-.052 \\
(.027) \\
\end{array}$ & $\begin{array}{l}-.084 \\
(.036) \\
\end{array}$ & $\begin{array}{l}-.023 \\
(.055) \\
\end{array}$ & $\begin{array}{l}.616 \\
(.031) \\
\end{array}$ & $\begin{array}{r}.718 \\
(.123) \\
\end{array}$ & $\begin{array}{r}.349 \\
(.189) \\
\end{array}$ \\
\hline City Fixed Effects? & No & Yes & Yes & No & Yes & Yes \\
\hline $\begin{array}{l}\text { Region-Year } \\
\text { Interactions? }\end{array}$ & No & No & Yes & No & No & Yes \\
\hline p-value: instruments & $<.001$ & $<.001$ & .01 & .034 & .021 & .048 \\
\hline R-squared & .280 & .294 & .429 & .257 & .334 & .426 \\
\hline
\end{tabular}


Notes to Table 3: Dependent variables are changes in per capita city crime in columns 1-3 and $\Delta$ In(city population) in columns 4-6. Sample is comprised of annual observations from 1976-1993 for 137 U.S. central cities with population greater than 100,000 in population in 1973. Year and region dummies are included in all specifications. Due to missing data, number of observations is equal to 2,301 in columns $1-3$ and 2,412 in columns 4-6. Prison commitment and release data are defined at the state level and are changes in rates per reported crime. All variables are available annually, except for \% black, which is linearly interpolated between decennial census years. See Table 1 for further information about the level of geographic disaggregation of the covariates. Estimates control for heteroskedasticity by city size. Standard errors in parentheses. The bottom row of the table gives the joint significance of an F-test of the four prison variables. 
Table 4: 2SLS Estimates of the Impact of Crime on City Population

\begin{tabular}{|c|c|c|c|c|c|}
\hline \multirow[b]{2}{*}{ Variable } & \multicolumn{3}{|c|}{ All cities in sample } & \multirow{2}{*}{$\begin{array}{c}\text { Cities }<4 \% \\
\text { of state pop. } \\
(4) \\
\end{array}$} & \multirow{2}{*}{$\begin{array}{r}\begin{array}{r}\text { Cities }>4 \% \\
\text { of state pop. }\end{array} \\
\text { (5) }\end{array}$} \\
\hline & (1) & $(2)$ & (3) & & \\
\hline $\begin{array}{l}\Delta \text { (Per Capita City } \\
\text { Crime) }\end{array}$ & $\begin{array}{l}-1.34 \\
(.59)\end{array}$ & $\begin{array}{r}-1.43 \\
(.57)\end{array}$ & $\begin{array}{l}-2.03 \\
(.92)\end{array}$ & $\begin{array}{l}-2.60 \\
(1.57)\end{array}$ & $\begin{array}{l}-1.64 \\
(1.23)\end{array}$ \\
\hline $\begin{array}{l}\Delta \text { (Per Capita } \\
\text { Suburban Crime) }\end{array}$ & $\begin{array}{l}.67 \\
(.19)\end{array}$ & $\begin{array}{l}.68 \\
(.19)\end{array}$ & $\begin{array}{l}.68 \\
(.23)\end{array}$ & $\begin{array}{l}1.27 \\
(.79)\end{array}$ & $\begin{array}{l}.51 \\
(.26)\end{array}$ \\
\hline $\begin{array}{l}\text { Unemployment Rate } \\
(-1)\end{array}$ & $\begin{array}{l}-.044 \\
(.032)\end{array}$ & $\begin{array}{l}-.137 \\
(.051)\end{array}$ & $\begin{array}{l}-.261 \\
(.073)\end{array}$ & $\begin{array}{l}-.080 \\
(.088)\end{array}$ & $\begin{array}{l}-.431 \\
(.131)\end{array}$ \\
\hline $\begin{array}{l}\text { State Per Capita } \\
\text { Income }{ }^{*} 10^{6}(-1)\end{array}$ & $\begin{array}{l}.16 \\
(.59)\end{array}$ & $\begin{array}{c}.66 \\
(1.37)\end{array}$ & $\begin{array}{c}1.15 \\
(2.71)\end{array}$ & $\begin{array}{l}5.92 \\
(4.86)\end{array}$ & $\begin{array}{c}.24 \\
(3.96)\end{array}$ \\
\hline$\%$ black $(-1)$ & $\begin{array}{l}-.032 \\
(.005)\end{array}$ & $\begin{array}{l}.037 \\
(.040)\end{array}$ & $\begin{array}{l}-.021 \\
(.044)\end{array}$ & $\begin{array}{l}.025 \\
(.081)\end{array}$ & $\begin{array}{l}-.082 \\
(.068)\end{array}$ \\
\hline$\%$ aged $0-17(-1)$ & $\begin{array}{l}-.042 \\
(.086)\end{array}$ & $\begin{array}{l}-.584 \\
(.180)\end{array}$ & $\begin{array}{l}-.266 \\
(.297)\end{array}$ & $\begin{array}{l}-.946 \\
(.667)\end{array}$ & $\begin{array}{l}-.120 \\
(.420)\end{array}$ \\
\hline$\%$ aged $18-24(-1)$ & $\begin{array}{l}.568 \\
(.132)\end{array}$ & $\begin{array}{l}-.671 \\
(.297)\end{array}$ & $\begin{array}{l}-.337 \\
(.416)\end{array}$ & $\begin{array}{c}-.996 \\
(1.238)\end{array}$ & $\begin{array}{l}-.339 \\
(.616)\end{array}$ \\
\hline$\%$ aged $25-44(-1)$ & $\begin{array}{l}-.053 \\
(.079)\end{array}$ & $\begin{array}{l}-.989 \\
(.270)\end{array}$ & $\begin{array}{r}-.930 \\
(.409)\end{array}$ & $\begin{array}{c}-1.432 \\
(.889)\end{array}$ & $\begin{array}{l}-.970 \\
(.581)\end{array}$ \\
\hline$\%$ aged $45-64(-1)$ & $\begin{array}{l}.185 \\
(.154)\end{array}$ & $\begin{array}{l}-.646 \\
(.247)\end{array}$ & $\begin{array}{l}-.481 \\
(.583)\end{array}$ & $\begin{array}{l}-.106 \\
(.870)\end{array}$ & $\begin{array}{l}-.280 \\
(.847)\end{array}$ \\
\hline $\begin{array}{l}\% \Delta \text { state population } \\
(-1)\end{array}$ & $\begin{array}{l}.517 \\
(.103)\end{array}$ & $\begin{array}{c}.592 \\
(.134)\end{array}$ & $\begin{array}{l}.330 \\
(.200)\end{array}$ & $\begin{array}{l}-.161 \\
(.418)\end{array}$ & $\begin{array}{l}.284 \\
(.278)\end{array}$ \\
\hline City Fixed Effects? & No & Yes & Yes & Yes & Yes \\
\hline $\begin{array}{l}\text { Region-year } \\
\text { interactions }\end{array}$ & No & No & Yes & Yes & Yes \\
\hline $\begin{array}{l}\text { p-value: } \\
\text { overidentifying } \\
\text { restrictions }\end{array}$ & .135 & .070 & .039 & .346 & .035 \\
\hline
\end{tabular}

$\begin{array}{llllll}\text { Number of Obs. } & 2,140 & 2,140 & 2,140 & 1,183 & 957\end{array}$

Notes: Dependent variable is $\Delta \ln$ (city population). Sample is comprised of annual observations from 1976-1993 for 137 U.S. central cities with population greater than 100,000 in population in 1973 .

Year and region dummies are included in all specifications except those where region-year interactions are present. Once- and twice-lagged state prison commitment and release rates per crime are used as instruments in all columns. The P-value of an $\mathrm{NR}^{2}$ test of overidentifying restrictions on instruments is reported in table. All variables are available annually, except for \% black, which is linearly interpolated between decennial census years. Estimation allows for heteroskedasticity by city population. Standard errors in parentheses. 


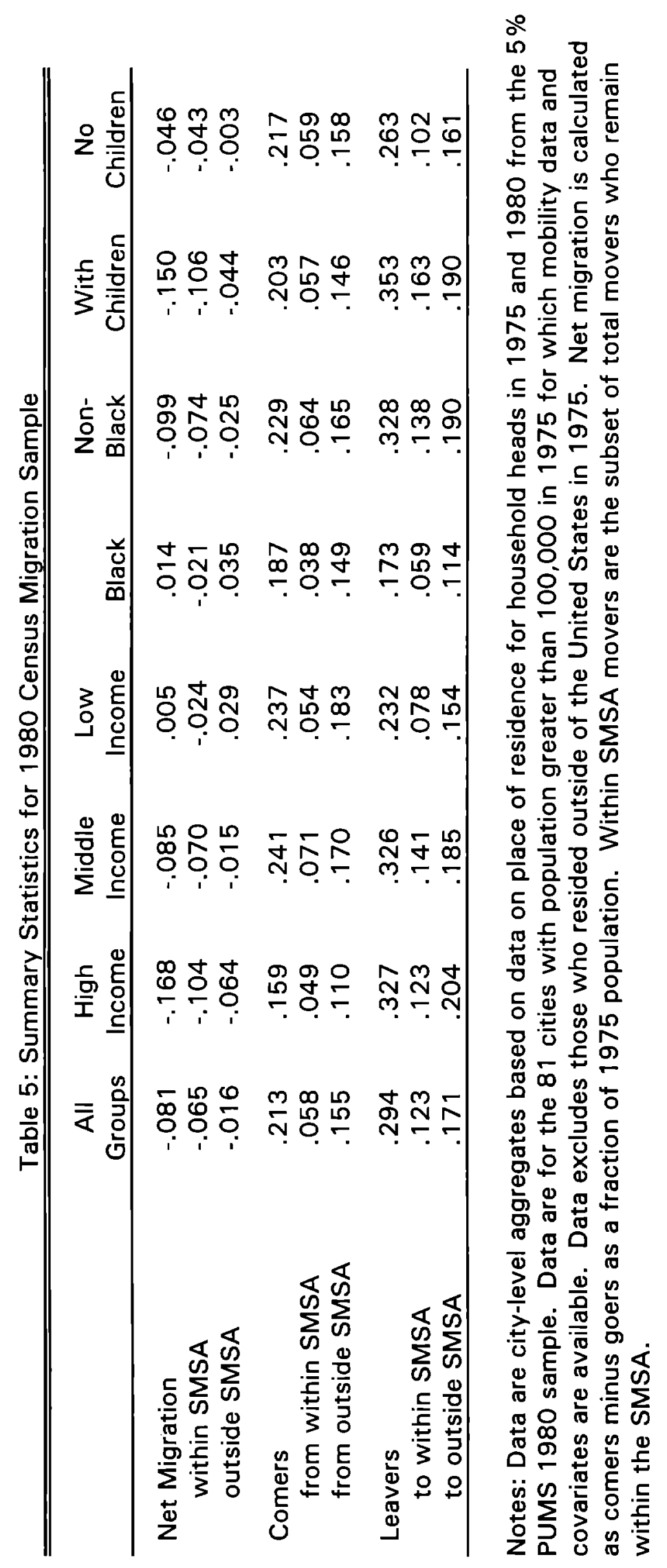




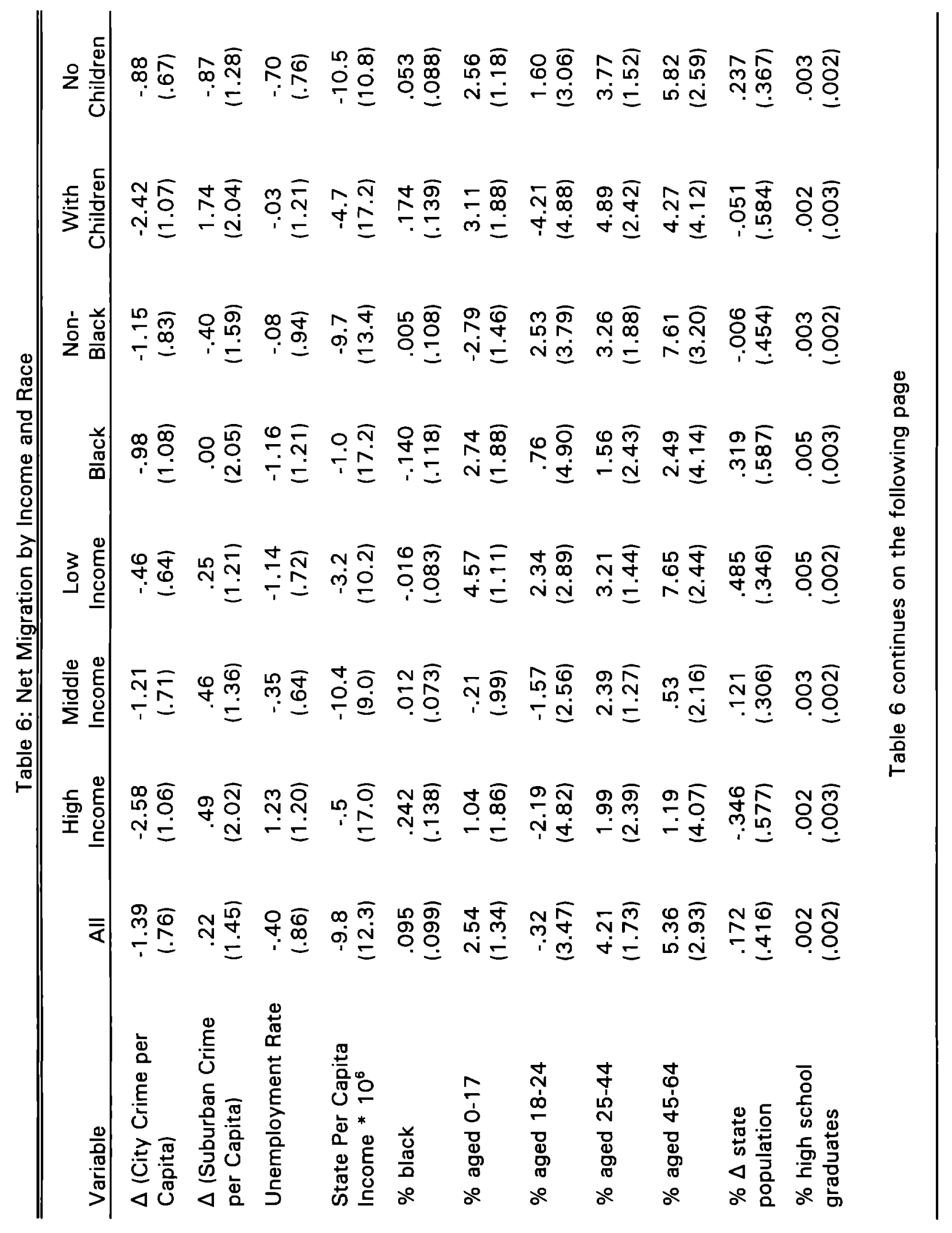




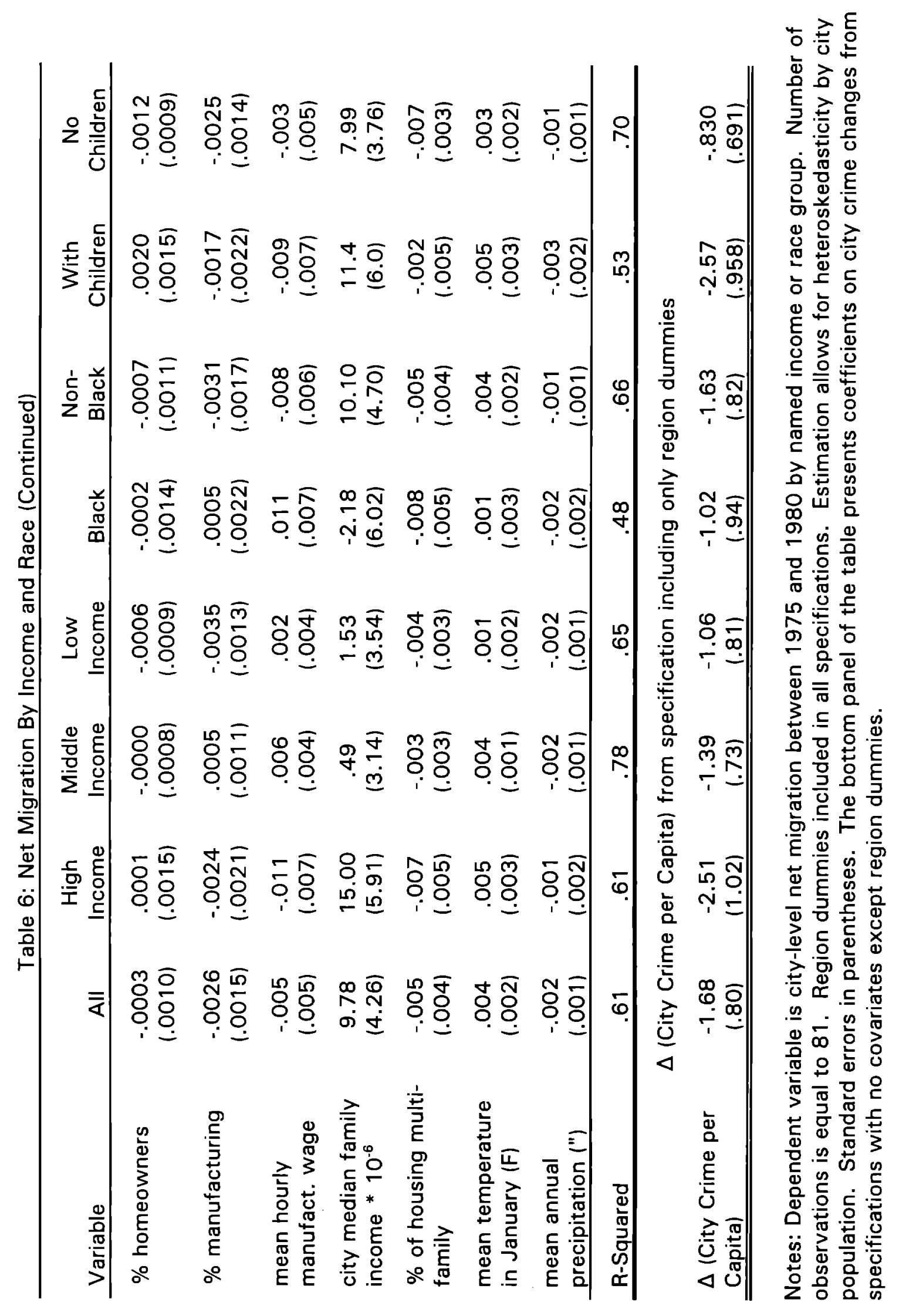




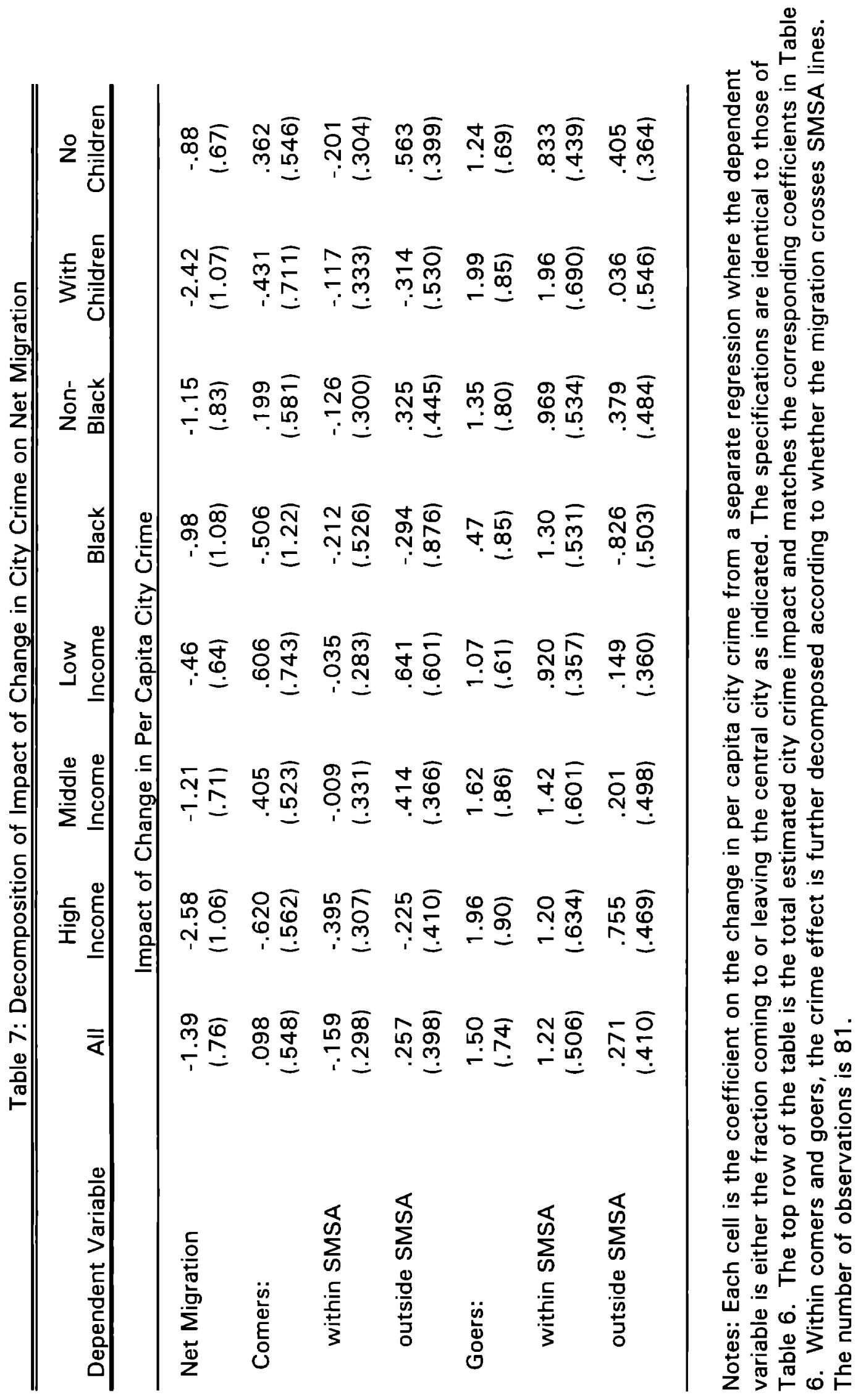




\begin{tabular}{|c|c|c|c|c|c|}
\hline Variable & \multicolumn{2}{|c|}{ All Household Heads } & \multirow{2}{*}{$\begin{array}{c}\text { High Income } \\
-1.59 \\
(.632)\end{array}$} & \multirow{2}{*}{$\begin{array}{c}\begin{array}{c}\text { Middle } \\
\text { Income }\end{array} \\
\begin{array}{c}-1.53 \\
(.637)\end{array}\end{array}$} & \multirow{2}{*}{$\begin{array}{c}\text { Low Income } \\
\begin{array}{c}-1.15 \\
(.465)\end{array}\end{array}$} \\
\hline$\Delta$ Per Capita Crime in City & $\begin{array}{l}-1.61 \\
(.72)\end{array}$ & $\begin{array}{l}-1.40 \\
(.56)\end{array}$ & & & \\
\hline $\begin{array}{l}\triangle \text { Per Capita Suburban } \\
\text { Crime }\end{array}$ & $\begin{array}{c}1.61 \\
(1.01)\end{array}$ & $\begin{array}{l}1.03 \\
(.83)\end{array}$ & $\begin{array}{r}.797 \\
(1.02)\end{array}$ & $\begin{array}{l}1.12 \\
(.970)\end{array}$ & $\begin{array}{l}1.17 \\
(.678)\end{array}$ \\
\hline Years of Education & - & $\begin{array}{l}-.009 \\
(.001)\end{array}$ & $\begin{array}{l}-.007 \\
(.001)\end{array}$ & $\begin{array}{l}-.011 \\
(.001)\end{array}$ & $\begin{array}{c}-.008 \\
(.0004)\end{array}$ \\
\hline $\begin{array}{l}\text { Income Group: } \\
\text { Middle }\end{array}$ & - & $\begin{array}{l}.018 \\
(.005)\end{array}$ & - & - & - \\
\hline High & - & $\begin{array}{l}.024 \\
(.009)\end{array}$ & - & - & - \\
\hline Age & - & $\begin{array}{l}.006 \\
(.001)\end{array}$ & $\begin{array}{l}.010 \\
(.001)\end{array}$ & $\begin{array}{l}.007 \\
(.001)\end{array}$ & $\begin{array}{c}.005 \\
(.0004)\end{array}$ \\
\hline Male & - & $\begin{array}{l}.027 \\
(.002)\end{array}$ & $\begin{array}{l}.025 \\
(.006)\end{array}$ & $\begin{array}{l}.030 \\
(.003)\end{array}$ & $\begin{array}{l}.017 \\
(.003)\end{array}$ \\
\hline Black & - & $\begin{array}{l}.148 \\
(.019)\end{array}$ & $\begin{array}{l}.159 \\
(.019)\end{array}$ & $\begin{array}{l}.149 \\
(.020)\end{array}$ & $\begin{array}{l}.132 \\
(.019)\end{array}$ \\
\hline Has Own Children & - & $\begin{array}{l}.022 \\
(.005)\end{array}$ & $\begin{array}{l}.014 \\
(.006)\end{array}$ & $\begin{array}{l}.018 \\
(.005)\end{array}$ & $\begin{array}{l}.046 \\
(.008)\end{array}$ \\
\hline Married & - & $\begin{array}{l}-.036 \\
(.004)\end{array}$ & $\begin{array}{l}-.023 \\
(.009)\end{array}$ & $\begin{array}{l}-.037 \\
(.004)\end{array}$ & $\begin{array}{l}-.050 \\
(.005)\end{array}$ \\
\hline Homeowner & - & $\begin{array}{l}.014 \\
(.024)\end{array}$ & $\begin{array}{l}-.013 \\
(.042)\end{array}$ & $\begin{array}{l}.015 \\
(.024)\end{array}$ & $\begin{array}{l}.036 \\
(.015)\end{array}$ \\
\hline Armed forces 1975 & - & $\begin{array}{l}-.276 \\
(.019)\end{array}$ & $\begin{array}{l}-.229 \\
(.023)\end{array}$ & $\begin{array}{l}-.277 \\
(.018)\end{array}$ & $\begin{array}{l}-.267 \\
(.030)\end{array}$ \\
\hline College student 1975 & - & $\begin{array}{l}-.100 \\
(.009) \\
\end{array}$ & $\begin{array}{r}-.100 \\
(.010) \\
\end{array}$ & $\begin{array}{l}-.082 \\
(.008) \\
\end{array}$ & $\begin{array}{l}-.090 \\
(.010) \\
\end{array}$ \\
\hline $\begin{array}{l}\text { Controls from City-level } \\
\text { Regressions }\end{array}$ & Yes & Yes & Yes & Yes & Yes \\
\hline R-squared & .029 & .152 & .158 & .155 & .142 \\
\hline Observations & 402042 & 402042 & 73277 & 197089 & 131676 \\
\hline \multicolumn{6}{|c|}{ Comparable Coefficient from City-level Regression } \\
\hline$\Delta$ Per Capita Crime in City & $\begin{array}{r}-1.50 \\
(.74) \\
\end{array}$ & $\begin{array}{r}-1.50 \\
(.74) \\
\end{array}$ & $\begin{array}{r}-1.96 \\
(.90) \\
\end{array}$ & $\begin{array}{r}-1.62 \\
(.86)\end{array}$ & $\begin{array}{r}-1.07 \\
(.61)\end{array}$ \\
\hline
\end{tabular}


Notes to Table 8a: The sample includes only households residing in one of the 81 central cities included in the sample in 1975. The dependent variable is an indicator equal to one if the household remains in the central city in 1980, and zero otherwise. The complete set of state and city-level regressors are included in these specifications: state real per capita income and age distribution variables in 1975, state population growth 1975 to 1980 , SMSA unemployment rate 1975 , city \% black, \% graduating high school, \% housing owner occupied, median family income in 1970, \% manufacturing, mean hourly wage in manufacturing, \% multi-family housing, climate controls, and region dummies. We allow for correlation in the error term across households in a given city so as not to understate the standard errors. 
Table 8b: Household-level Estimates of the Decision to Stay in Central Cities (Con't)

\begin{tabular}{|c|c|c|c|c|}
\hline Variable & Black & $\begin{array}{l}\text { Non- } \\
\text { Black }\end{array}$ & With Children & No Children \\
\hline$\Delta$ Per Capita Crime in City & $\begin{array}{l}-1.72 \\
(.59)\end{array}$ & $\begin{array}{l}-1.34 \\
(.599)\end{array}$ & $\begin{array}{l}-1.80 \\
(.635)\end{array}$ & $\begin{array}{l}-1.14 \\
(.528)\end{array}$ \\
\hline $\begin{array}{l}\Delta \text { Per Capita Suburban } \\
\text { Crime }\end{array}$ & $\begin{array}{c}2.32 \\
(1.21)\end{array}$ & $\begin{array}{l}1.04 \\
(.930)\end{array}$ & $\begin{array}{c}1.47 \\
(.982)\end{array}$ & $\begin{array}{l}.641 \\
(.837)\end{array}$ \\
\hline Years of Education & $\begin{array}{l}-.007 \\
(.001)\end{array}$ & $\begin{array}{l}-.010 \\
(.001)\end{array}$ & $\begin{array}{l}-.013 \\
(.001)\end{array}$ & $\begin{array}{l}-.007 \\
(.001)\end{array}$ \\
\hline $\begin{array}{l}\text { Income Group: } \\
\text { Middle }\end{array}$ & $\begin{array}{l}-.003 \\
1.006)\end{array}$ & $\begin{array}{l}.026 \\
(.005)\end{array}$ & $\begin{array}{l}-.006 \\
(.005)\end{array}$ & $\begin{array}{l}.023 \\
(.005)\end{array}$ \\
\hline High & $\begin{array}{l}-.008 \\
1.009)\end{array}$ & $\begin{array}{l}.033 \\
(.010)\end{array}$ & $\begin{array}{l}-.010 \\
(.010)\end{array}$ & $\begin{array}{l}.032 \\
(.010)\end{array}$ \\
\hline Age & $\begin{array}{c}.004 \\
(.0003)\end{array}$ & $\begin{array}{l}.006 \\
(.001)\end{array}$ & $\begin{array}{l}.009 \\
(.001)\end{array}$ & $\begin{array}{l}.006 \\
(.001)\end{array}$ \\
\hline Male & $\begin{array}{l}.024 \\
(.003)\end{array}$ & $\begin{array}{l}.024 \\
(.003)\end{array}$ & $\begin{array}{l}.052 \\
(.007)\end{array}$ & $\begin{array}{l}.017 \\
(.003)\end{array}$ \\
\hline Black & - & - & $\begin{array}{l}.166 \\
(.026)\end{array}$ & $\begin{array}{l}.129 \\
(.014)\end{array}$ \\
\hline Has Own Children & $\begin{array}{l}.033 \\
(.005)\end{array}$ & $\begin{array}{l}.013 \\
(.006)\end{array}$ & - & - \\
\hline Married & $\begin{array}{l}-.028 \\
(.003)\end{array}$ & $\begin{array}{l}-.038 \\
(.005)\end{array}$ & $\begin{array}{l}-.030 \\
(.004)\end{array}$ & $\begin{array}{l}-.032 \\
(.003)\end{array}$ \\
\hline Homeowner & $\begin{array}{l}.019 \\
(.016)\end{array}$ & $\begin{array}{l}.016 \\
(.026)\end{array}$ & $\begin{array}{l}-.010 \\
1.0301\end{array}$ & $\begin{array}{l}.028 \\
(.021)\end{array}$ \\
\hline Armed forces 1975 & $\begin{array}{l}-.198 \\
(.025)\end{array}$ & $\begin{array}{l}-.287 \\
(.018)\end{array}$ & $\begin{array}{l}-.258 \\
(.016)\end{array}$ & $\begin{array}{l}-.270 \\
(.837)\end{array}$ \\
\hline College student 1975 & $\begin{array}{l}-.083 \\
(.010) \\
\end{array}$ & $\begin{array}{r}-.100 \\
1.009) \\
\end{array}$ & $\begin{array}{l}-.056 \\
(.010) \\
\end{array}$ & $\begin{array}{l}-.117 \\
(.010) \\
\end{array}$ \\
\hline $\begin{array}{l}\text { Control from City-level } \\
\text { Regressions }\end{array}$ & Yes & Yes & Yes & Yes \\
\hline R-squared & .094 & .146 & .144 & .158 \\
\hline Observations & 88360 & 313682 & 135787 & 266255 \\
\hline \multicolumn{5}{|c|}{ Comparable Coefficient from City-level Regression } \\
\hline$\Delta$ Per Capita Crime in City & $\begin{array}{l}-.47 \\
(.85)\end{array}$ & $\begin{array}{r}-1.35 \\
(.80)\end{array}$ & $\begin{array}{r}-1.99 \\
(.85)\end{array}$ & $\begin{array}{r}-1.24 \\
(.69)\end{array}$ \\
\hline
\end{tabular}

Notes: See notes to Table 8a. 


\section{Bibliography}

Beattie, John, 1995, "Crime and Inequality in Eighteenth-Century London," in Crime and Inequality, J. Hagan and R. Peterson (eds.), Stanford: Stanford University Press.

Benabou, Roland, 1993, "Workings of a City: Location, Education, and Production," Quarterly Journal of Economics 108:619-652.

Bergstrom, Theodore and Robert Goodman, 1973, "Private Demands for Public Goods," American Economic Review 63:280-296.

Blanchard, Olivier and Lawrence Katz, 1992, "Regional Evolutions," Brookings Papers on Economic Activity, 1-61.

Blanchard, Olivier and Lawrence Summers, 1987, "Fiscal Increasing Returns, Hysteresis, Real Wages, and Unemployment," European Economic Review 31:543-566.

Bradbury, Katharine, Anthony Downs, and Kenneth Small, 1982, Urban Decline and the Future of American Cities, Washington, DC: Brookings.

Bradford, David, and Harry Kelejian, 1973, "An Econometric Model of the Flight to the Suburbs," Journal of Political Economy 81:566-589.

Bureau of Justice Statistics, 1994, Criminal Victimization in the United States, 1992 , Washington DC: Bureau of Justice Statistics.

Case, Anne and Lawrence Katz, 1991, "The Company You Keep: the Effects of Family and Neighborhood on Disadvantaged Youths," NBER Working Paper.

Cohen, Mark, 1988, "Pain, Suffering, and Jury Awards: A Study of the Cost of Crime to Victims," Law and Society Review 22:537-555.

Cutler, David and Edward Glaeser, 1995, "Are Ghettos Good or Bad?" NBER Working Paper.

Dilulio, John, and Anne Piehl, 1991, "Does Prison Pay? The Stormy National Debate over the Cost-effectiveness of Imprisonment," The Brookings Review (fall), 28-35.

Frey, William H., 1979, "Central City White Flight: Racial and Nonracial Causes," American Sociological Review 44:425-448.

Glaeser, Edward, and Bruce Sacerdote, 1996, "Why is There more Crime in Cities," NBER Working Paper No.5430.

Glendon, Spencer, 1996, "Metropolitan Housing Choice: Families, Crime, and Social Interactions," Mimeo, Harvard University.

Gonzalez, Rudolfo and Stephen Mehay, 1987, "Economies of City Size in a Price Searcher 
Model of Local Government," Public Finance 42:236-249.

Gottdeiner, Mark (editor), 1986, Cities in Stress: A New Look at Urban Crisis, Beverly Hills: Sage.

Grubb, W. Norton, 1982, "The Flight to the Suburbs of Population and Employment, 196070," Journal of Urban Economics 11:348-367.

Hellman, Daryl and Joel Naroff, 1979, "The Impact of Crime on Urban Residential Property Values," Urban Studies 16:105-112.

Inman, Robert, Steven Craig, and Thomas Luce, 1994, "The Fiscal Future for American Cities: Lessons from Three Cities," Research Impact Paper \#4, Wharton Real Estate Center, University of Pennsylvania.

Katzman, Martin, 1980, "The Contribution of Crime to Urban Decline," Urban Studies 17:277-286.

Ladd, Helen, and Katherine Bradbury, 1988, "City Taxes and Property Tax Bases," National Tax Journal 41:503-523.

Ladd, Helen, and Julie Boatright Wilson, 1983, "Who Supports Tax Limitations: Evidence from Massachusetts' Proposition 2 1/2," Journal of Policy Analysis and Management 2:256-279.

Levitt, Steven, 1995, "The Relationship between Crime Reporting and Police: Implications for the Use of Uniform Crime Reports," Mimeo, Harvard University.

Levitt, Steven, 1996, "The Effect of Prison Population Size on Crime Rates: Evidence from Prison Overcrowding Litigation," Quarterly Journal of Economics 111:319-352.

Marshall, Harvey, 1979, "White Movement to the Suburbs: A Comparison of Explanations," American Sociological Review 44:975-994.

Marshall, Harvey, and Kathleen O'Flaherty, 1987, "Suburbanization in the Seventies: The 'Push-Pull' Hypothesis Revisited," Journal of Urban Affairs 9:249-262.

Marvell, Thomas and Carlisle Moody, 1994, "Prison Population Growth and Crime Reduction," Journal of Quantitative Criminology 10:109-140.

Miller, Ted, Mark Cohen and Shelli Rossman, 1993, "Victim Costs of Violent Crime and Resulting Injuries," Health Affairs 12:186-197.

Monkkonen, Eric, 1981, Police in Urban America, 1860-1920, New York: Cambridge University Press.

O'Brien, Robert, 1985, Crime and Victimization Data, Beverly Hills: Sage.

Sampson, Robert J. and John D. Wooldredge, 1986, "Evidence that High Crime Rates 
Encourage Migration Away from Central Cities," Sociology and Social Research 90:310-314.

Schwartz, Joe, 1987, "On the Road Again," American Demographics 9 (April) :38-42.

Smith, Barton, 1978, "Measuring the Value of Urban Amenities," Journal of Urban Economics 5:370-387.

Smith, D.R., and G.R. Jarjoura, 1988, "Social Structure and Criminal Victimization, "Social Structure and Criminal Victimization," Journal of Research in Crime and Delinquency 25:27-52.

Spelman, William, 1994, Criminal Incapacitation, New York: Plenum.

Taeuber, Karl and Alma Taeuber, 1964, "White Migration and Socioeconomic Differences between Cities and Suburbs," American Sociological Review 29:718-729.

Taylor, R. and J. Covington, 1988, "Neighborhood Changes in Ecology and Violence," Criminology 26:553-590.

Thaler, Richard, 1978, "A Note on the Value of Crime Control: Evidence from the Property Market," Journal of Urban Economics 5:137-145.

U.S. Bureau of the Census, 1993, City Government Finances: 1990-1991, Series GF/91-4, Washington, DC: U.S. Government Printing Office.

Wilson, William Julius, 1987, The Truly Disadvantaged: The Inner City, the Underclass, and Public Policy, Chicago: University of Chicago Press.

Yinger, John and Helen Ladd, 1989, "The Determinants of State Assistance to Central Cities," National Tax Journal 42:413-428. 